\title{
同時連立方程式による地価変動波及メカニズムに関する研究
}

\section{The mechanism of repercussion of land price variation by simultaneous equation model}

\author{
廣瀬 義伸*, 青山 吉隆**, 井上 雅晴***
}

Yoshinobu HIROSE, Yoshitaka AOYAMA, Masaharu INOUE

\section{1. 研究の背景と目的}

地価の変動は、本来その土地固有の効用に基づいて 決定される地価が、社会資本の整備や社会・経済構造 といった外的要因の変化に伴って生じると考えられる。

しかし、1980年代中頃に始まった異常な地価の高騰、 そしてその後の下落が、東京都都心部より発生し、全 国に波及したのは、その当時絶頂期を迎えていたバブ ル景気による地価上昇への期待形成と、用途間および 地域間で地価変動が波及したことに起因していたと指

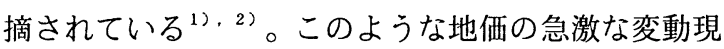
象は、土地の不良債権問題をはじめ、わが国の経済・ 社会の様々な面に大きなマイナスの影響を及ぼしてお り、二度とこのような現象が生じないような対策を検 討することが肝要である。

既に、我々はこの最近の 10 年間における地価変動現 象を対象として地価変動の波及メカニズムについて分

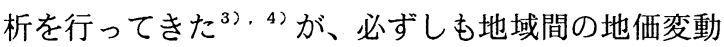
の連関構造を十分に説明したとはいえない。

本研究の特徴は、やはり近年の地価高騰現象を対象 としているが、ある地点の地価変動が他の地点の地価 変動に影響を与えたとしか考えられないような現象に 着目し、経済的な要因や金融的な要因の他に、用途間 および空間的な地価上昇の伝播作用を説明する空間波 及要因を地価変動の重要な要因として考慮してモデル 分析を試みたところにある。具体的には、地価変動に ついて、時系列的に連続したクロスセクションデータ を用い、地価変動要因の相互依存関係を明らかにする ために、連立方程式体系を用いて地価波及要因分析モ デルの推定を行うことにより、地価変動要因に関する 実証的な分析を試みている。

キーワード : 地価分析，都市計画

*正会員 工修 徳島大学工学部建設工学科助手

（三770 徳島市南常三島町2-1, Te1.0886-56-7340, FAX. 0886-56-7341） **正会員 工博 京都大学大学院工学研究科教授

***正会員 工修 (株) ニュージェック

\section{2. 分析の方法}

本研究では用途地域のうち容積率規制および建物用 途規制といった土地利用規制の類似しているものを統 合し、表一 1 に示す 2 つ用途系を設定した。

\section{表-1 用途地域区分結果}

\begin{tabular}{|l||c|}
\hline 用途系 & 用途地域 \\
\hline \multirow{3}{*}{ 住居系 } & 第 1 種住居専用地域住居尃用地域 \\
\cline { 2 - 2 } & 住居地域 \\
\hline 商業系 & 商業地域 \\
\hline
\end{tabular}

当初の分析の地域単位は、東京都については、特別 区を都心部、区部北東部、区部南西部に、残りを市部 と郡部の合計 5 ゾーンに分割した。また、政令指定都 市が含まれる道府県では、政令指定都市、政令指定都 市を除く市部、郡部の 3 ゾーンに分割した。その他の 県は全県で1つのゾーンとした。しかし、モデルの推 定においては、それまでの分析の結果を踏まえて、こ れらのゾーンを適宜統合して推計を行っている。

使用する地価データ ${ }^{5)}$ は、地価公示地点の更新など の影響を除外するために、対象期間を通じて地価公示 がなされている地点を抽出した。分析対象期間は、19 75年以降の地価公示地点数の各年別の残存数 ${ }^{6)}$ より、 1983 1993年の11年間とした。分析に用いた地域別用 途系別対前年地価平均変動率（以下、平均変動率）の 算出式を式(1)に示す。

$$
\begin{gathered}
g p_{k, t}=\frac{1}{N} \sum_{i=1}^{N}\left(\frac{P_{i, t}-P_{i, t-1}}{P_{i, t-1}} \times 100\right) \\
\left(\begin{array}{ll}
i & : \text { 地域 } k \text { にまれる地点 }(i=1,2, \cdots \cdots N) \\
t & : \text { 時点 }(t=1983,1984, \cdots \cdots 1993) \\
P_{i t} & : \text { : 地点 } \mathrm{i} \text { における } \mathrm{t} \text { 期の地価 } \\
g p_{k,} & : \text { : 地域 } k \text { における } \mathrm{t} \text { 期の平均変動率 }
\end{array}\right.
\end{gathered}
$$




\section{3. 地域間と用途系間の地価変動の関連分析}

モデルによる地価変動の波及構造の分析に先立ち、 全国の地価変動の動向について、平均変動率を用いて、 地域間および用途系間の地価変動の関連性を分析した。

\section{（1） ゾーン別用途系別平均変動率の推移}

まずはじめに、いくつかのゾーンにおける平均変動 率の推移を分析した。

図一 1 は、東京都都心部のグラフである。地価の上 昇は1985年頃に商業系から生じ、ピークとなる1987年 には住居系が $100 \%$ 以上の変動を示した後一気に変 動率が低下し、1993年には大幅な下落を示している。

続いて、近畿圈の代表として大阪市における推移を 図ー 2 に示す。東京都都心部亡ほぼ同様の経緯をたど っているが、大きな地価上昇が生じ始めたのは、東京 都都心部から 2 年遅れの 1987 年であり、ピークは 3 年 遅れの1990年である。しかし、地価が下落し始めたの は東京都都心部之同時期である。さらに、地方圈の代 表として徳島県における変動率の推移を図ー 3 に示す。 徳島県における地価変動は、大都市と比べると小幅で あるが、明らかに変動の経緯が酷似している。また、 地価上昇の発生時期は東京都都心部より $3 \sim 4$ 年遅れ ているが、下落期はほぼ同時期であることがわかる。

これらの図より明らかなように、地価変動はまず商 業系より住居系へと時計回りの円や「逆S」字を描く ように推移しており、東京, 大阪, 徳島の順に上昇が 生じている。しかし、地価高騰が終息し、下落に転じ ている時期はほぼ同じであることがわかる。

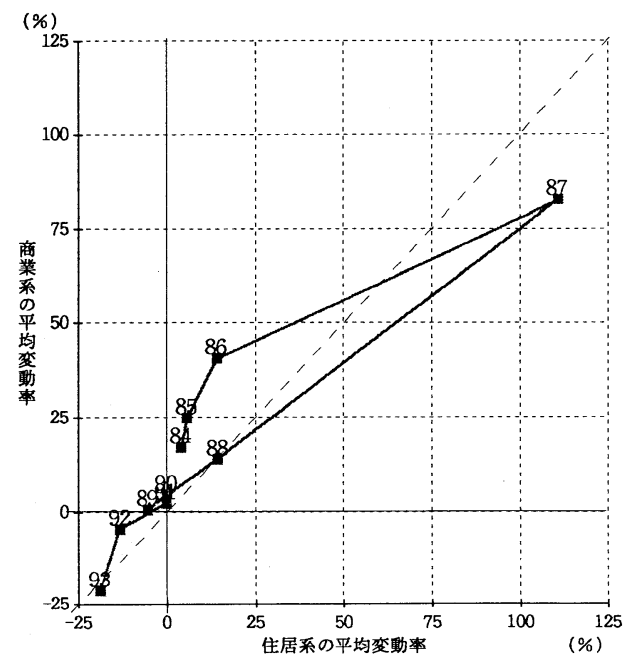

図-1 東京都都心部における平均変動率の推移

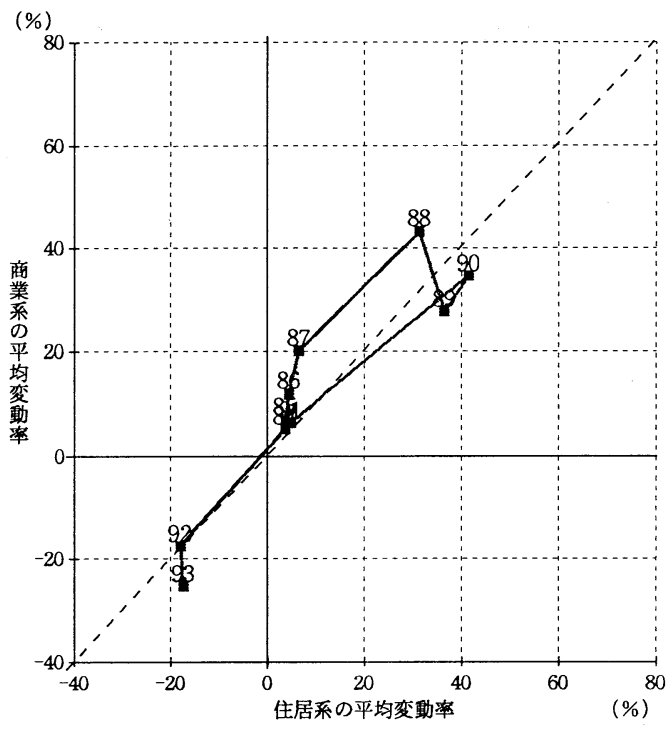

図-2 大阪市における平均変動率の推移

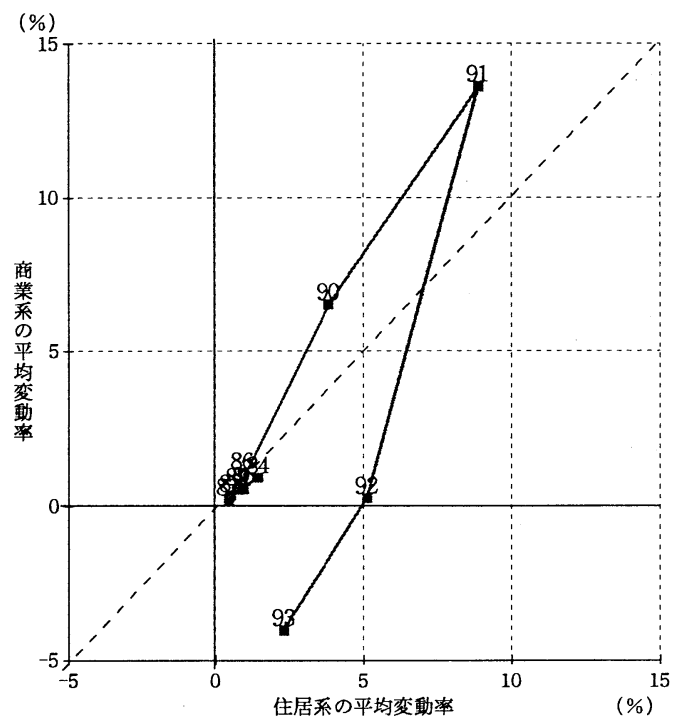

図 -3 徳島県全域における平均変動率の推移

\section{（2）ゾーン間および用途系間の相関分析}

表一 2 は、東京都都心部に対する各ゾーンの地域間 および用途系間の地価変動の関連性をみるために、士 0 年〜 +3 年の間で時間をずらしながら相関分析を行 った結果である。この表より、地域間の地価変動では、 東京都心部が最も先行しており、東京都心部の周辺の ゾーンおよび首都圈が続き、以下近畿圈の大都市部、 その他の大都市部、地方圈の順に地洒変動が生じてい たことが明らかになった。この時の地域間の地価変動 の波及のタイムラグは $1 \sim 3$ 年であり、商業系と住居 系はほぼ同様の結果であった。 
また、同一ゾーン内の用途系間の地価変動の波及に ついて平均変動率による相関分析を行った結果、首都

\section{表一2 東京都心部に対する各ゾーン用途系の相関分析の結果}

\begin{tabular}{|c|c|c|c|c|}
\hline タイムラク & \pm 0 年 & +1 年 & +2 年 & +3 \\
\hline パターン & (1):(2) & (4) & (1) & (1):(2) (3) \\
\hline 東区部南西 & (০):-(O) & & & \\
\hline 京区部北東 & (0): & & & \\
\hline 都笁 部 & & Q̄:@ & & \\
\hline 郡 部 & - & - (O) - (O) & -1 & - \\
\hline 埼 浦和市 & & (০:০:০:০ & & \\
\hline 玉 市 部 & & (a) (a) & & \\
\hline 県 郡 部 & & & $\triangle$ & 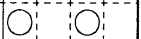 \\
\hline 千 千葉市 & & & & \\
\hline 葉 市 部 & & & & \\
\hline 県 郡 部 & - & - & - & $-\triangle_{1}-\triangle$ \\
\hline 神 横浜市 & & & & \\
\hline 奈川崎市 & & & & \\
\hline 川市 部 & & & & \\
\hline 県 郡 部 & & & - & \\
\hline 京京都市 & & & $\triangle$ & O:(O) \\
\hline 都市 部 & & & & (0): \\
\hline 府郡 部 & - & & - & - \\
\hline 大 大阪市 & & $\mathrm{O}$ & & O:(0): \\
\hline 阪 市 部 & & & & (Q):(0) \\
\hline 府郡 部 & - & - & 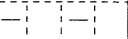 & - \\
\hline 兵 神戸市 & & & & (1):(0): \\
\hline 庫 市 部 & & & & 0 \\
\hline 県郡 部 & - & - & - & $\triangle \triangle^{-}$ \\
\hline 愛名古屋市 & & $\Delta$ & & $0:$ \\
\hline 知 市 部 & & & & $0: 0$ \\
\hline 県郡 部 & & & & 0 \\
\hline 北 札幌市 & & $\triangle$ & & $0: \triangle$ \\
\hline 海市 部 & & & & $\triangle X^{\prime}$ \\
\hline 道郡 部 & & & & $\times \times \triangle \triangle^{\prime}$ \\
\hline 宮 仙台市 & & $\triangle$ & & \\
\hline 城 市 部 & & & & $\triangle \triangle \triangle$ \\
\hline 県 郡 部 & & & & $0: 0$ \\
\hline 広 広島市 & & $\triangle$ & & $0: 0: 0$ \\
\hline 島 部 & & & & $0: \triangle$ \\
\hline 県 郡 部 & & & & $0: 0: 0: 0$ \\
\hline 福 福岡市 & & $0: 0:$ & & \begin{tabular}{|l:l}
$\triangle$ & $\triangle$ \\
\end{tabular} \\
\hline 岡北九州市 & & & & $\times: \times: \times 1$ \\
\hline 県市 部 & & & & $\triangle X \triangle X$ \\
\hline 郡 部 & & & & 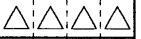 \\
\hline その他全国 & & : & & $0: \triangle: O$ \\
\hline
\end{tabular}

凡例 :

パターン (1): 都心部商業系 $\rightarrow$ 各地域商業系

(2)：都心部商業系 $\rightarrow$ 各地域住居系

(3)：都心部住居系 $\rightarrow$ 各地域商業系

(4)：都心部住居系 $\rightarrow$ 各地域住居系

相関係数 (0)：0．8 以上

$\bigcirc: 0.6 \sim 0.8$

$\triangle: 0.4 \sim 0.6$

$\times: 0.4$ 未満
圈の一部のゾーンでは商業系が住居系に対して 1 年先 行して変動が生じていたが、その他のゾーンでは両方 の用途系でほぼ同時に同程度の地価変動が生じていた ことが明らかになった。

\section{（3）クラスター分析による地域の類型化}

さらに、平均変動率によるゾーン別のクラスター分 析を行ったところ、大きく分類して、表一 3 に示すよ うに、東京都・首都圈中心都市部・首都圈郊外部・大 都市圈・地方圈の 5 つに分類された。

\section{4. 同時連立方程式による地価波及構造分析モテル}

\section{（1） モデルの推定手順}

モデル推定の手順は、同時連立方程式の構造型モデ ルを、地域間および用途系間の地価変動に関する関連 分析から得た結果と、過去の分析から得た地価変動に 関連する外的要因についての知見に基づいて定める。 続いて、その方程式群の誘導型を導き、最小自乗法を

\section{表ー3 ゾーン別用途系別クラスター分析の結果}

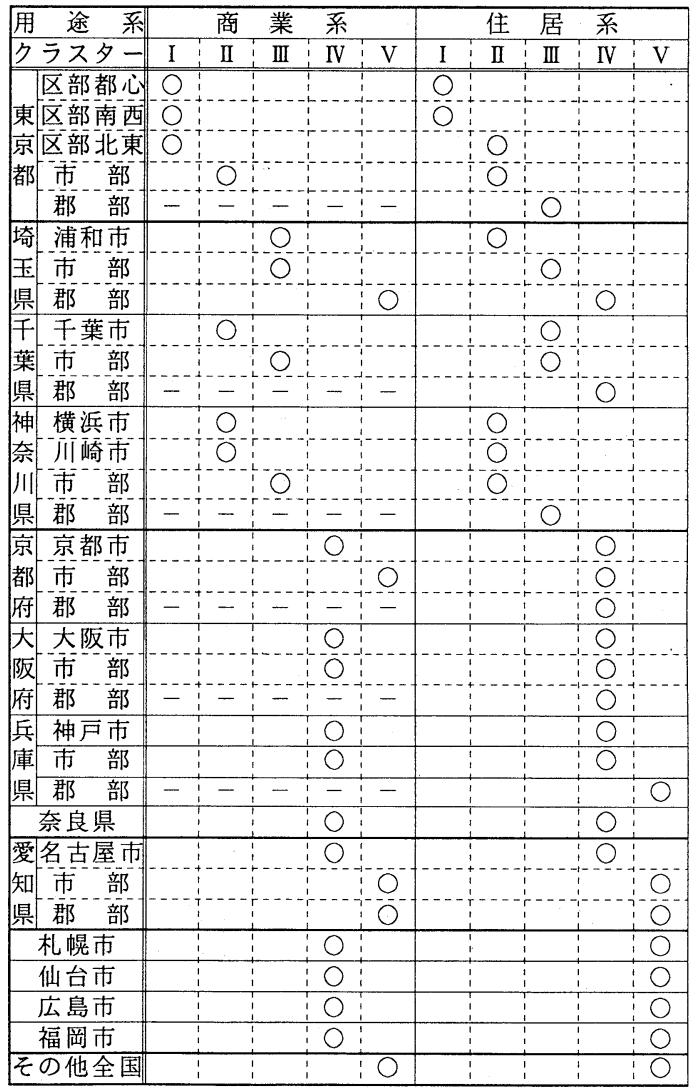


適用して構造型の右辺にある内生変数を推計する。こ の誘導型に対する最小自乗法による推計値を構造型に 代入し、再び最小自乗法を適用して構造型モデルのパ ラメー夕を推定する。変数の選択は、空間波及および 用途間波及に関する先の分析の結果をモデル式に反映 することと、符号条件および最も良い $\mathrm{t}$ 值が得られる ことを重視して行った。

\section{（2）要因の選定}

同時連立方程式による地価変動の波及構造モデルの 推定に際し、基本となる構造型モデルには、先の地域 間および用途系間の地価変動に関する関連分析に基つ く要因と、地価変動に影響すると考えられる経済・金 融・所得等の外的要因を加えた。

モデル推定の対象期間は、構造型では1987〜1993年 とする。モデルの推定は、先の相関分析とクラスター 分析に基づいて、表- 4 に示す 4 グループを設定し、 各々 4 つのゾーンを抽出して行った。このため標本数 は28टなる。また、外的要因としては、地価変動に関 連すると考えられる種々の要因を選び出し、モデルの 推定に用いたが、最終的に採用された説明変数として は、表一 6 に示すとおりとなった。また、誘導型によ って求められた内生変数を空間的波及要因、用途間波 及要因として用いる。

\section{（3）地価変動波及構造モデルの推定結果}

ここで推計する地価波及構造分析モデルは、線形の 同時連立方程式モデルである。本モデルは、東京都、 首都圈、近畿圈、地方圈の 4 地域の商業系、住居系の

$$
\text { 表-4 モデルの推定に用いた地域 }
$$

\begin{tabular}{|c|c|}
\hline グループ & 抽出した地域 \\
\hline 東京都 & 都心部，区部南西部，区部北東部，東京都市部 \\
\hline 首都圈 & 埼玉県, 千葉県, 川崎・横浜, 川崎・横浜を除く神奈川県 \\
\hline 近畿圈 & 京 都 府, 大阪 府, 兵 庫 県 \\
\hline 地方圈 & 山形県, 長野県, 徳島県, 宮崎県 \\
\hline
\end{tabular}

表-5 モデルに用いた説明変数

\begin{tabular}{|c|c|c|c|c|c|}
\hline \multirow{2}{*}{\multicolumn{2}{|c|}{ 済 }} & 変 & 名 & タイムラ & 種 \\
\hline & & 成 & 率 & +1 年 & 経済要因 \\
\hline & 定 歩 & & 変 化 & 年 & 金融要因 \\
\hline \multicolumn{4}{|c|}{ 不動産業貸出残高(全国)変化率| } & +1 年 & 金融要因 \\
\hline \multicolumn{4}{|c|}{ 不動産業貸出残高 (東京都)変化率 } & +0 年 & 金融要因 \\
\hline \multicolumn{4}{|c|}{ 不動産業貸出残高 (首都圈)変化率| } & +0 年 & 金融要因 \\
\hline \multicolumn{4}{|c|}{ 不動産業貸出残高 (近畿圈)変化率 } & +0 年 & 金融要因 \\
\hline \multicolumn{4}{|c|}{ 不動産業貸出残高(地方圈)変化率 } & +1 年 & \multirow{2}{*}{\begin{tabular}{|l|} 
金融要因 \\
所得要因
\end{tabular}} \\
\hline \multicolumn{4}{|c|}{ 一人当り平均所得 (近畿圈)変化率 } & +1 年 & \\
\hline
\end{tabular}

表 -6 地価変動波及構造モデルの推定結果

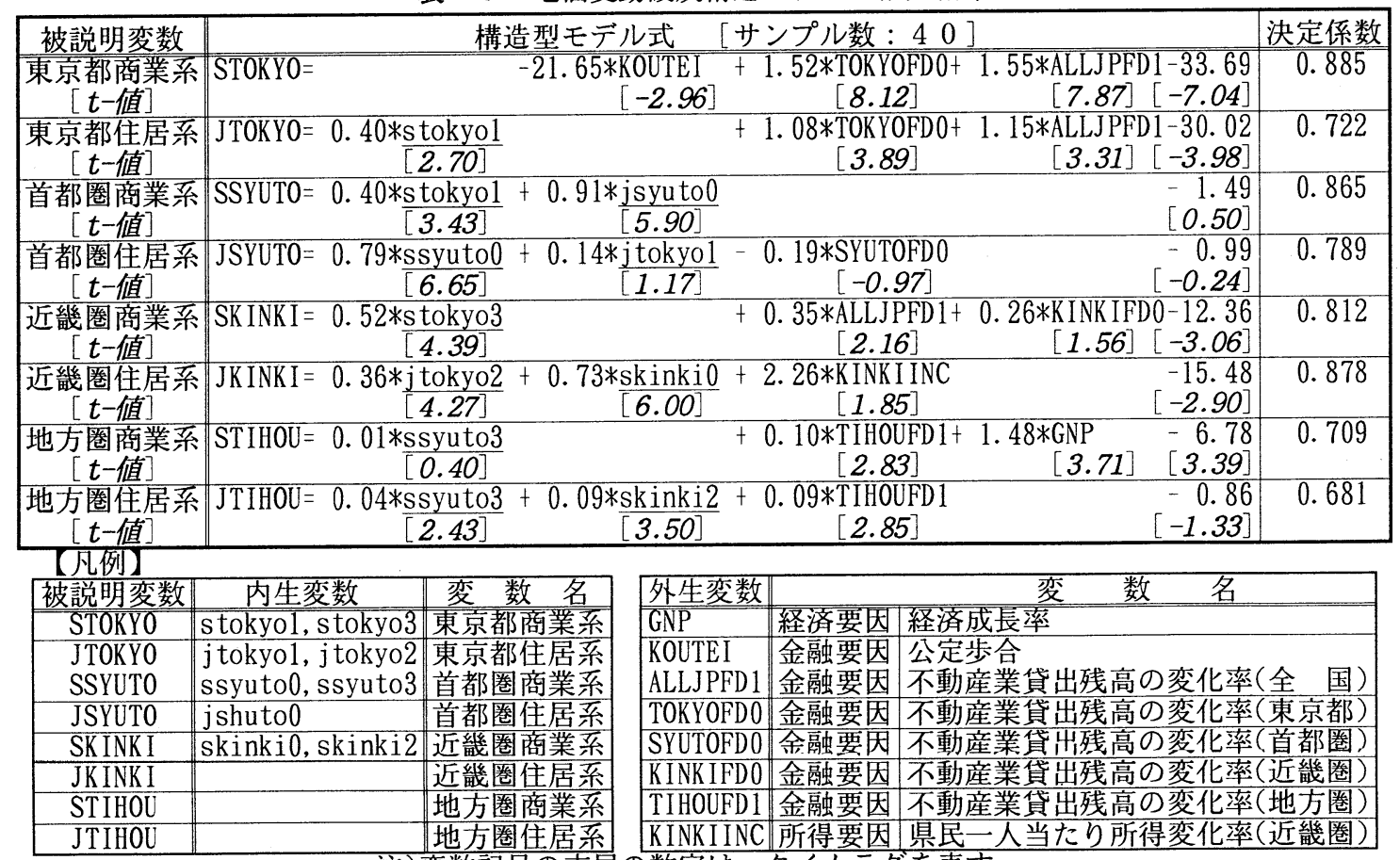

注)変数記号の末尾の数字は、タイムラグを表す。 
両用途系について推定されるため、合計 8 本の連立方 程式モデルとなる。このモデルに用いた説明変数を 表- 5 に示す。表一 6 は、構造型モデルの推定結果で ある。ただし、モデルに使用する外生変数のデー夕の うち、データが欠損している年次については、線形補 完によって算出した。なお、各モデル式の内生変数お よび外生変数の各変数記号の最後の数字は、夕イムラ グを表している。

\section{（4）モデルの推定結果に対する検討}

以下、推定されたモデル式の内生変数に着目して考 察する。今回の地価急騰の端緒である東京都の商業系 には、公定歩合、東京都の全国銀行不動産業貸出残高、 全国の不動産業貸出残高の金融および経済の要因のみ が含まれており、空間および用途間の波及要因は含ま れなかったため、これまでの分析結果を裏付ける結果 が得られた。また、東京都住居系のモデル式には、前 年の東京都商業系の変動率と金融要因が含まれており、 これも商業系から住居系への波及が存在したという仮 説を裏付ける結果が得られた。

首都圈の商業系のモデ式には、前年の東京都商業 系の変動率と同年の首都圈住居系の変動率が含まれ、 東京から首都圈への空間波及と同一地域内の用途間波 及が生じていることがわかる。また、首都圈住居系の モデル式には同年の首都圈の商業系と前年の東京都の 住居系の変数が含まれており、同一地域内の用途間の 波及と東京からの空間波及が存在したことがわかる。

近畿圈商業系のモデル式には、東京都の商業系の変 動が 3 年遅れで影響しており、これは空間の波及であ るといえる。また、近畿圈住居系のモデル式には、 2 年前の東京都住居系亡同年の近畿圈商業系が含まれて おり、用途間・空間の波及がともに存在したことにな る。

地方圈商業系のモデル式には、3 年前の首都圈商業 系が関与しているが、首都圈商業系のモデル式に前年 の東京都商業系が含まれていることより、東京都商業 系が 4 年の夕イムラグを経て影響を与えていると解釈 できる。しかし、この首都圈商業系の $\mathrm{t}$ 值がかなり低 いため、地方圈商業系の地価変動においては、空間波 及よりも地方圈不動産業貸出残高および経済成長率と いった外生変数の影響が強いとも解釈できる。最後の 地方圈の住居系のモデル式は、3 年前の首都圈商業系 と 2 年前の近畿圈の商業系が含まれている。これは、 用途間亡空間の波及が同時に生じていると解釈できる。
ここまでモデル式を吟味した結果を総合すると、モ デル式に含まれる内生変数の相互関係より、やはり東 京都の商業系の地価変動が、直接および間接的にその 他の地域の地価に影響を及ぼしていたことが明らかで あり、また地域間の地価の波及には夕イムラグが介在 していたことも明らかになった。以上の関係は、従来 の文献で指摘され、我々の現在までの地価変動とその 波及の現象の分析において得られた仮説と一致してお り、本研究の地価変動波及構造モデルによって先年の 急激な地価変動の波及メカニズムを明らかにしている と考えられる。

\section{5. モテルの検証と要因分解}

ここでは、地価変動波及構造モデルの検証と、地価 変動に寄与している要因についての考察を、グラフに よる要因分解によって分析する。ただし、ここで考察 の対象とする地域は、モデルの推定を行った 4 つのグ ループから、表- 7 に示す地域それぞれ 1 つ選び出し、 構造型モデルを用いて行う。

\section{表一 7 要因分解の対象とした地域}

\begin{tabular}{|l||l|l|l|}
\hline グループ名東京都首都圈近畿圏地方圏 \\
\hline \hline 選定地域 & 都心部 & 千葉市大阪府徳島県 \\
\hline
\end{tabular}

図－4の都心部商業系には、公定歩合(前年)之東京 都の不動産業貸出残高(同年)、そして、全国の不動産 業貸出残高(前年)の $3 つ の$ 金融的要因が含まれている。 この図より、地価変動には、金融要因である不動産業 貸出残高の変動が大きな影響を及ぼしているといえる。

図一 5 の都心部住居系においては、金融要因の全国 (前年)及び東京都(同年)の不動産業貸出残高、空間 ・ 用途波及要因として東京都商業系(前年)が含まれる。 1987年では、東京の不動産業貸出残高の寄与が大きい が、1988年以後は低下している。

図-6の千葉市商業系には、東京都商業系(前年)之 首都圈の住居系(同年)の 2 つの空間的波及要因のみが 含まれる。1989年までは東京都商業系と首都圈住居系 の影響は同程度であったが、1990 1992年には首都圈 住居系の用途波及要因の影響が大きくなっている。

図-7の千葉市住居系には、首都圈不動産業貸出残 高(同年)、東京都住居系(前年)之首都圈商業系(同年) の平均変動率が含まれる。図より、全般的に首都圈商 業系の用途間波及要因が、この地域の住居系には最も 
大きな影響を与えていることがわかる。

図一8の大阪府商業系においては、空間的波及要因 として、東京都商業系 ( 3 年前)、金融要因として全国 の不動産業貸出残高(前年)、近畿圈の不動産業貸出残 高(同年)が含まれている。この図より、地価が大きく 上昇している時期には、東京都商業系からの空間波及 要因の寄与が大きいことがわかる。

図-9の大阪府住居系では、波及要因として東京都 住居系 ( 2 年前) 之近畿圈商業系(同年)が、所得要因之 して近畿圈の県民一人当たり所得(前年)が含まれる。 1989 1990年の地価急騰期には、東京都住居系の波及

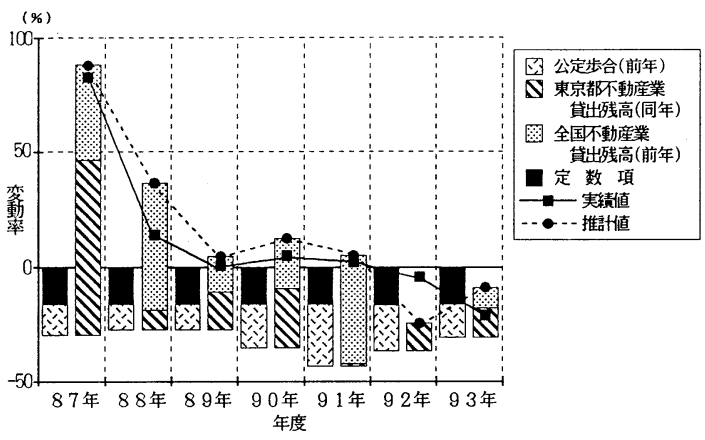

図 -4 都心部商業系の要因分解

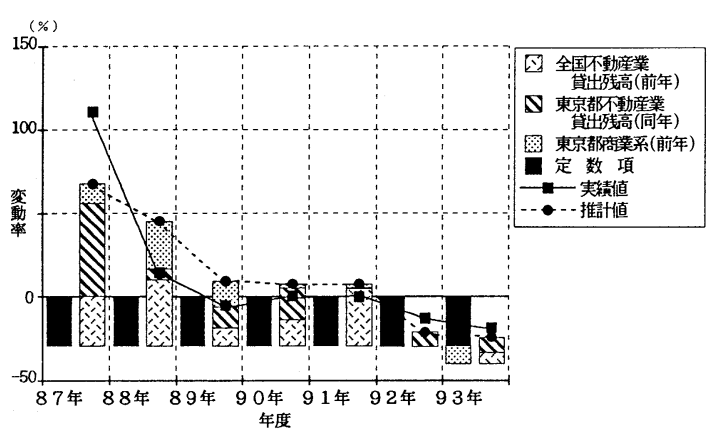

図 -5 都心部住居系の要因分解

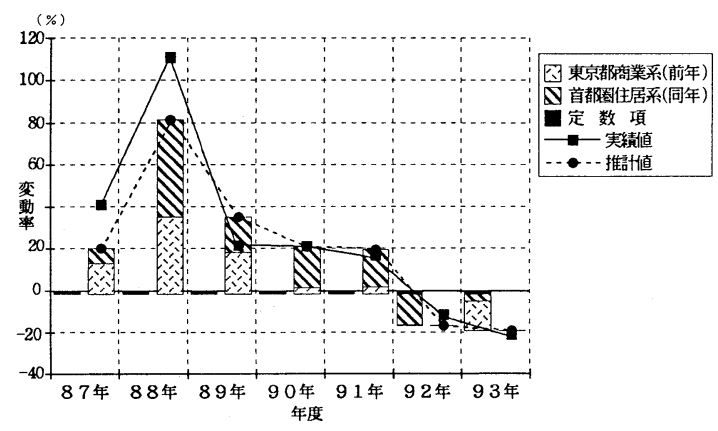

図-6 千葉市商業系の要因分解
要因が、近畿圈商業系の用途波及要因の寄与が大きい。

図-10の徳島県商業系では、空間波及要因として 首都圈商業系 $(3$ 年前)、金融要因として地方圈不動産 貸出残高(前年)、経済要因として国民総生産(前年)が 含まれている。地方圈の地価変動は比較的小さいが、 空間波及要因に比へ、経済的要因の影響が大きい。

図-11の徳島県住居系には、用途間および空間の 波及要因として首都圈商業系 ( 3 年前) と近畿圈商業系 ( 2 年前)、金融要因として地方圈の不動産業貸出残高 （前年）が含まれている。この図より、地価変動はそれ ほど大きくないものの、徳島県商業系と比へ、用途間 及び空間波及要因の影響が大きい点が異なっている。

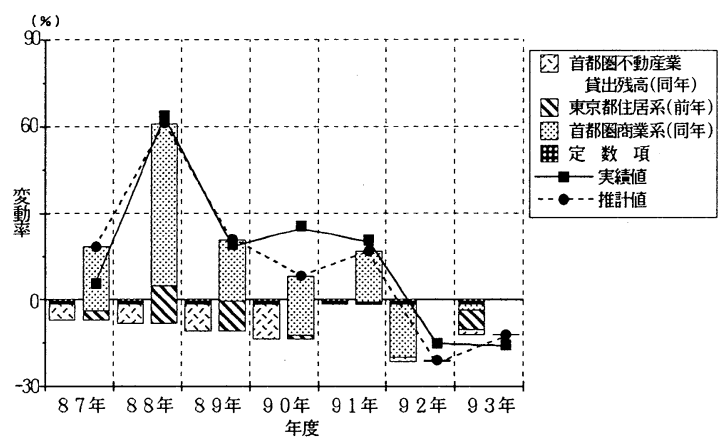

図 -7 千葉市住居系の要因分解

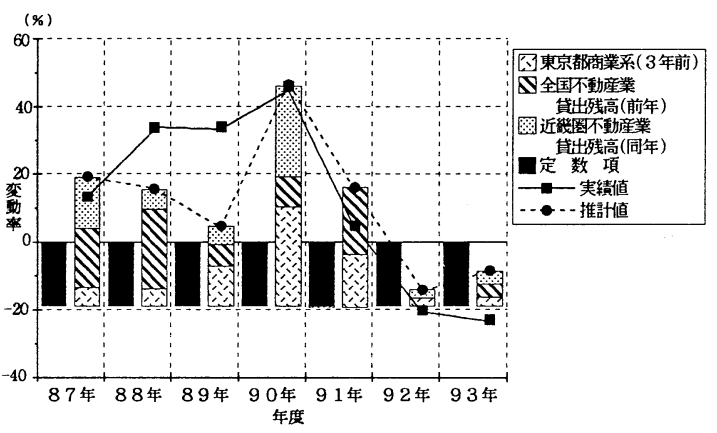

図 -8 大阪府商業系の要因分解

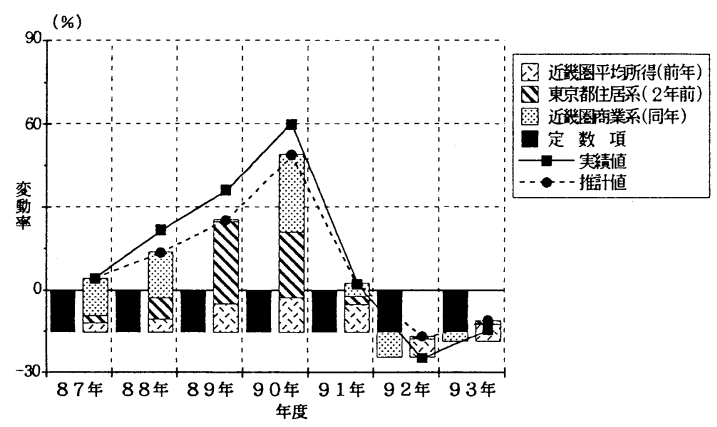

図 -9 大阪府住居系の要因分解 


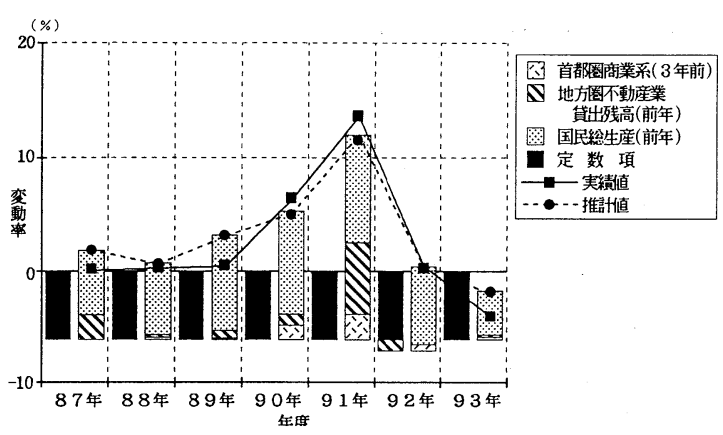

図-10 徳島県商業系の要因分解

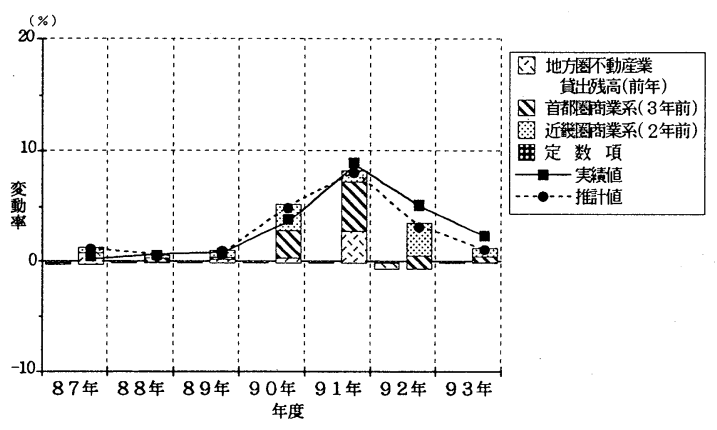

図-11 徳島県住居系の要因分解

\section{5. おわりに}

本研究では、地域別用途系別の対前年平均地価変動 率のデー夕を用いて、まず、平均変動率の単純な推移 と地域間および用途間の相関分析を行って、近年の地 価の急激な変動現象を概観した。その結果、商業系が 住居系にわずかに先行する形で地価が上昇した後、住 居系と商業系がほぼ同時に下落に転じたこと、東京都 の都心部が全国に先駆けて地価の急騰をみた後に、1 年から 4 年遅れて、首都圈, 他の大都市, 地方中枢都 市，地方圈の順に地価が上昇し、その後、ほぼ全国的 に同時に地価が下落に転じたことを明らかにした。

次に、地域別用途系別のクラスター分析を行い、地 価変動の類型が、東京都, 首都圈, 近畿圈, 地方圈の 4 つに大きく類型化されることを明らかにした。

さらに、ここまでで明らかになったことを踏まえて、 連立方程式による地価変動波及モデルを推定するとと もに、推定したモデルの精度の検証と地価変動とその 波及に寄与する要因の関係とその変化を明らかにする ために、要因分解を行って考察した。

推定された地価変動波及構造モデルは、充分満足の いく精度を有しており、外的要因である金融、経済、 所得の要因の他に、空間的波及要因、用途間波及要因
が東京都商業系を除く各モデル式に一つ以上含まれた ことより、地価変動の波及メカニズムには、地域間の 空間的波及之同一地域内および異なる地域間での用途 間波及が存在していたことが実証できた。さらに、こ のモデルによって、東京の商業系に端を発し、時間的 遅れを伴いながら地方へと拡大していった現象を忠実 に表現することができた。また、要因分解による分析 より、地価の高騰時には金融要因と地価の空間波及要 因および用途間波及要因が大きく寄与しており、地俩 の下落時には、これらの要因が非常に小さくなってい たことが明らかになった。

最後に、本研究で明らかになったことと実際の地価 変動に関わる社会情勢との関連について考察する。

まず、東京都における地価の上昇が全国に波及した のは、多くの用途波及要因および空間波及要因がモデ ルに含まれていたことより、ある地域の地価の変動が 用途を越えて空間的に波及することを防止できない土 地制度に一因があるといえる。また、青山 ${ }^{7}$ が理論的 に証明したように、この当時の金融市場からの土地不 動産への莫大な投資と、その投資による乗数効果が大 きな影響を与えたことも、本研究のモデルに金融要因 が含まれたことから明らかである。

さらに、地価の急騰が全国的にほぼ同時に終息し、 下落に転じたのも、地価監視区域の設定や金融機関へ の不動産関連融資への総量規制をはじめとする土地対 策の影響を受けて金融要因の寄与が大幅に減少したこ とによるものと考えられる。

最後になったが、本研究は、(財)第一住宅建設協会 の助成を受けて実施している。また、地価公示デー夕 は、国土庁計画・調整局国土情報室より借用した。こ こに感謝の意を表する次第である。

\section{《参考文献》}

1)例えば、国土庁編:土地白書, 大蔵省印刷局, pp. 74-94, 1991

2)青山吉隆:土地市場への流入資金の乗数効果之空間 波及に関するマク口理論, 土木学会論文集, No.449/IV-17, pp. 185-192, 1992

3)青山吉隆・廣瀬義伸: 土地制度と地価の空間波及, 土木計画学研究講演集, №.15(2),pp. 117-122, 1992

4)廣瀬・青山・井上:地価の空間波及要因に関するパネ ルデータ分析, 土木計画学研究講演集, No.17, pp. 139-142, 1995

5)国土庁土地鑑定委員会編:地価公示

6)安藤朝夫・内田隆一・吉田克明: 2 大都市圈における 地価関数の推定結果を用いた地価変動の時空間分 析, 土木学会論文集, №.449/IV-17, pp. 77-86, 1992 7)前出2) 


\section{同時連立方程式による地価変動波及メカニズムに関する研究}

廣瀬 義伸，青山 吉隆，井上 雅晴

本研究では、最近10年間の地域別用途系別の対前年平均地価変動率のデー夕を用いて、連立方程式モ デルを推定した。さらに、推定したモデルの精度の検証と、地価変動および地価変動の波及に奇与して いた要因を明らかにするために、グラフを用いた要因分解を行って分析した。その結果、地価変動には、 金融・経済・所得の要因の他に、空間的波及要因や用途間波及要因といった波及要因が関係しているこ とが明らかになり、地価変動には地域間の空間的波及と同一地域内および異なる地域間での用途間波及 のメカニズムが存在していることが実証できた。さらに、このモデルによって、地価変動が東京都都心 部の商業系に端を発し、時間的遅れを伴いながら地方へと拡大していった現象の構造をモデルにおいて 忠実に表現することができた。

The mechanism of repercussion of land price variation by simultaneous equation model

By Yoshinobu HIROSE, Yoshitaka AOYAMA and Masaharu INOUE

Japan had experienced the sudden rise and fall of land price for last ten years, which had never occured before. The sudden change in land price caused many social and economical problems.

This study aims to explain the mechanism of the repercussion in land price variation between regions. By analysing multi-crosssectional data, we found that there was a phenomenon of spatial repercussion in land price variation. We also analysed the factors of repercussion in land price variation by a model analysis using simultaneous equation model. 